\title{
The Application of Safety Education in Primary School Directorate in Indonesia
}

\author{
Evi Widowati, Herry Koesyanto, Sugiharto \\ Department of Public Health Science, Universitas Negeri Semarang, Indonesia
}

\begin{tabular}{|c|c|}
\hline Article Info & ABSTRACT \\
\hline Article history: & \multirow{9}{*}{$\begin{array}{l}\text { Primary school children are included in the vulnerable group because they } \\
\text { are still in a growth and development phase. In Indonesia, many accidents } \\
\text { involve children due to their lack of knowledge, excessive energy, and high } \\
\text { curiosity. Therefore, it is important to evaluate the application of safety } \\
\text { values in formal education material, in order to evaluate how adequate the } \\
\text { current teaching materials in encouraging children to practice safety culture. } \\
\text { Petompon } 2 \text {, one of the primary school used in this study, showed that } 60 \% \\
\text { subjects in grade } 1 \text { contain application of safety values, and subjects from } \\
\text { grade } 2 \text { to } 6 \text { showed that } 14.3 \%, 90 \%, 100 \%, 87.5 \% \text {, and } 50 \% \text { subjects, } \\
\text { consecutively, already contain safety education. The solutions offered are } \\
\text { improving teacher's capacity in learning process and integrating the safety } \\
\text { values into education subjects, such as: in sport education, natural science, } \\
\text { social science, citizenship education, Islamic religion, mathematics, and } \\
\text { Indonesian language. Other methods available are integrating safety values } \\
\text { into extracurricular activities and introducing educative game on safety } \\
\text { values to primary school students. }\end{array}$} \\
\hline Received Oct 5, 2017 & \\
\hline Revised Apr 24, 2018 & \\
\hline Accepted May 8, 2018 & \\
\hline Keywords: & \\
\hline Children & \\
\hline Education & \\
\hline Primary school & \\
\hline Safety & \\
\hline
\end{tabular}

Copyright $(0) 201 x$ Institute of Advanced Engineering and Science. All rights reserved.

\section{Corresponding Author:}

Evi Widowati,

Department of Public Health Science,

Universitas Negeri Semarang,

Building F5, $2^{\text {nd }}$ Floor, IKM FIK Universitas Negeri Semarang, Indonesia

Email: eviwidowati@mail.unnes.ac.id

\section{INTRODUCTION}

Primary school students are still in their growth and development phase, hence they are included in the vulnerable group. They are actively moving and have excessive energy and high curiosity to new things around them. Therefore, accidents could occur when they are playing, exercising, crossing the road and walking home which can cause panic for the school. Therefore, efforts to prevent accident involving children is needed, either by by improving teacher's role as the students' guardian at school or through other methods. Other preventive ways are cultivating safety culture through simple ways, such as Monday ceremony speech about self-safety during walking, crossing, cycling, exercising, driving or in emergency situations including fire, earthquake, and others [1].

It is a fact that generally, all human activities have potential risk to endanger self and others. Early safety education could prevent accidents which may cause minor or severe injuries, fainting, lifelong disability, and even death [2].

In his research, Hidayat stated that children between 5-13 years old need supervision from adults [3]. Examples of accidents based on data from School Health Unit (UKS) of PL Bernadus 02 Semarang found that students experience accidents during their activities in school such as falling and sprain during walking, running out of the bathroom, exercising and running around the classroom. From the data, 9 students experienced injuries and 5 must be reffered to the hospital due to fracture and sprain [4]. 
Formal education subjects are important in providing basic knowledge to children. In Indonesia, substantial amount of subjects are being crammed into the curriculum and is minimally integrated with application of safety education for children. Safety education can be integrated into formal education through learning material, teacher's explanation during class and learning facilities, or even integrated into extracurricular activities.

SD Negeri Petompon 2 is a representation of primary schools in Indonesia. The adequacy of safety education in its curriculum has not been evaluated yet. This research aimed to evaluate whether the teaching materials and facilities for grade 1-6 students contain adequate safety education for children, therefore we could understand whether safety values has become a priority in Indonesian primary school education system or not.

\section{RESEARCH METHOD}

The study design used was quantitative descriptive study with observational approach. This design was used to carefully describe a phenomenon without any intervention and prioritizing objectivity. Observational approach was used because the data was obtained from observation.

Data collection was conducted through document study and Forum group Discussion (FGD). The document study was conducted by reviewing all learning materials from grade 1-6 subjects whether they contain safety education explicitly and implicitly. Afterwards, FGD was conducted to complete the result of document study. During FGD, teachers clarify additional materials or explanation that was given as elaboration of available subjects.

The study informants were teachers and school management who provided information on the theory and application of safety value application among primary school students. Data collected was analyzed despcritive-quantitative in the form of percentages.

\section{RESULTS AND DISCUSSION}

SD Petompon 2 Kota Semarang used 2 types of curriculum. Grade 1 and 4 used 2013 thematic curriculum, while other grades used conventional 2006 curriculum.

\subsection{The Application of Safety Education in Grade 1 Primary School}

2013 curriculum applied in grade 1 . There were 10 thematic subjects: 1 (me and myself), 2 (my hobby), 3 (my activities), 4 (my family), 5 (my experience), 6 (clean and healthy environment), 7 (things, animals, and plants around me), 8 (natural events), Islamic and moral education, and Javanese language.

$60 \%$ of subjects in grade 1 contain safety education with details as follows: $50 \%$ of theme $1,25 \%$ of theme $3,25 \%$ of theme $5,50 \%$ of theme $7,25 \%$ of theme 8 and $20 \%$ of Islamic religion study already contain safety education as shown in Figure 1.

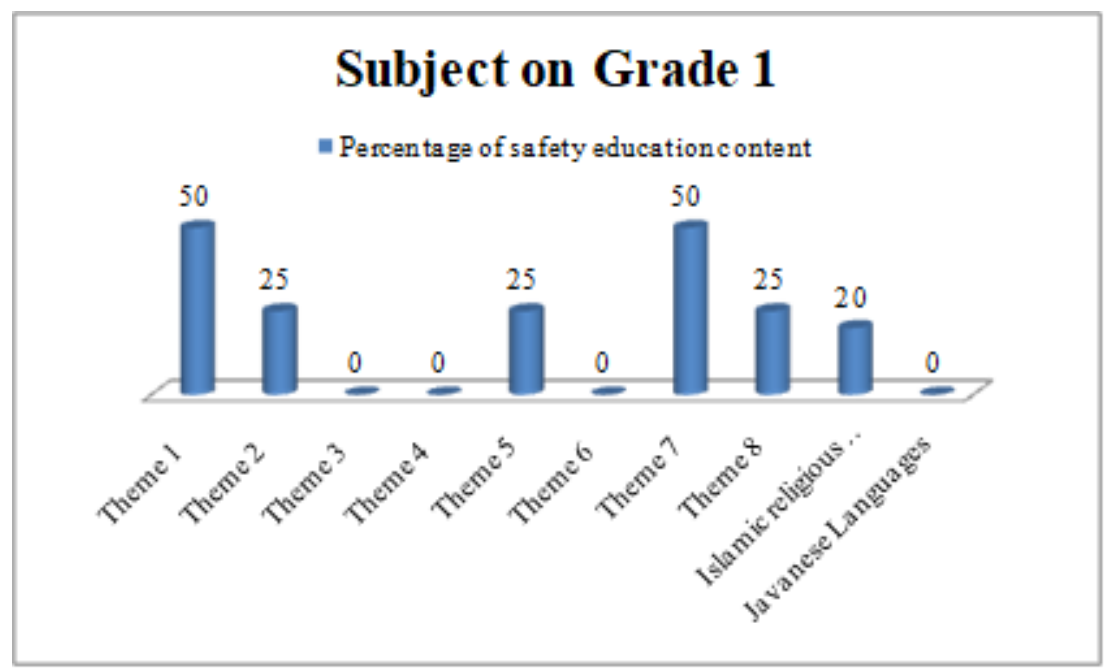

Figure 1. The illustration of safety education in grade 1 of primary school Source: Primary data, 2017 


\subsection{The Application of Safety Education in Grade 2 of Primary School}

There were 7 subjects taught in grade 2, namely: Citizenship education, Indonesian language, Mathematics, Natural Science, Social science, art \& culture, and Javanese language. Only one subject contain safety education, that is, citizenship education where $14.3 \%$ of the subject contain safety education. 2 out of 4 topics $(50 \%)$ in citizenship education contained safety education delivered $100 \%$ implicitly.

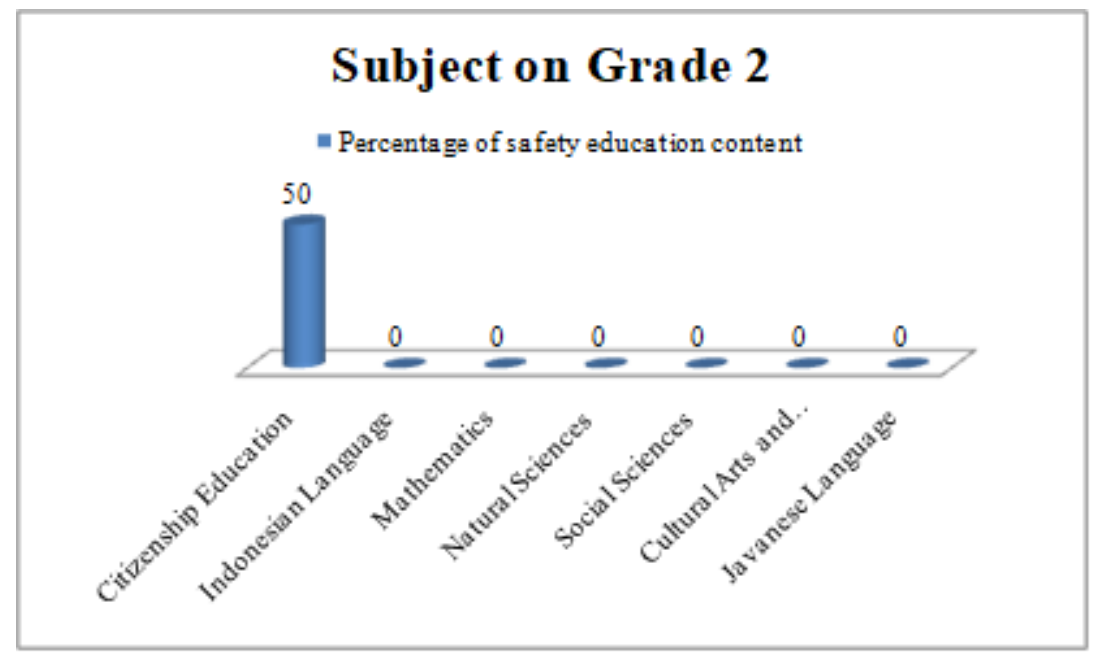

Figure 2. The illustration of safety education in grade 2 of primary school Source: Primary data, 2017

\subsection{The Application of Safety Education in Grade 3 of Primary School}

Grade 3 had 10 subjects, namely: natural science, social science, mathematics, Indonesian language, citizenship education, Islamic religion, Javanese language, sport education, art \& culture, and caring for self\& environment.

9 out of 10 subjects $(90 \%)$, except art \& culture, contain safety education presented both explicitly and implicitly. Natural science, Indonesian language, Mathematics, Citizenship education, Islamic religion, social science, Javanese language, sport, and caring for self \& environment contain safety education about $92 \%, 63 \%, 10 \%, 28 \%, 25 \%, 16 \%, 44 \%, 100 \%$, and $72 \%$ consecutively.

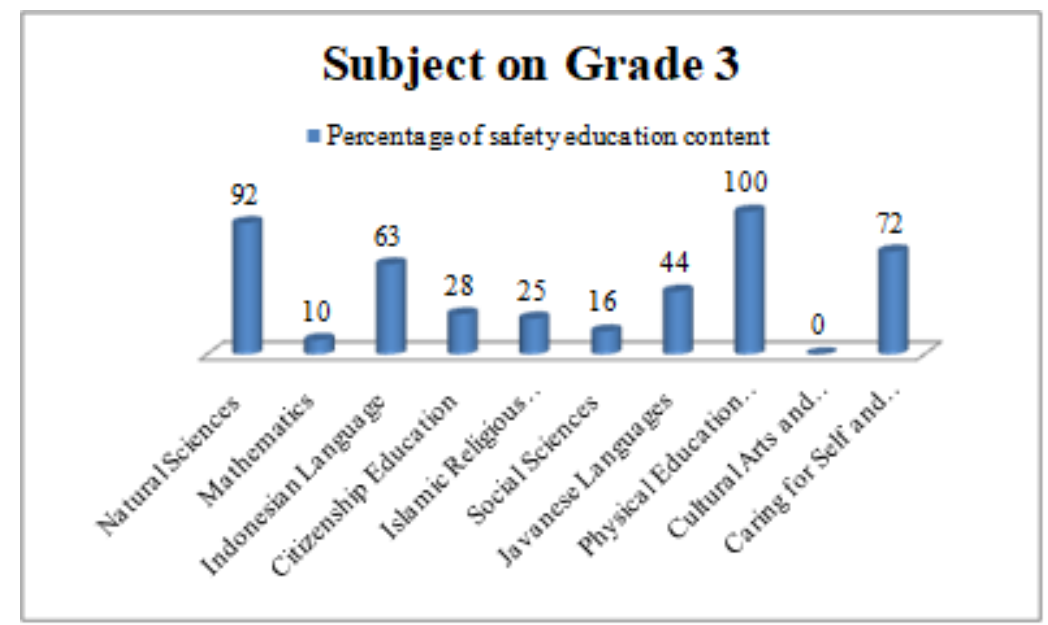

Figure 3. The illustration of safety education in grade 3 of primary school Source: Primary data, 2017 


\subsection{The Application of Safety Education in Grade 4 of Primary School}

Grade 4 of SD Petompon 2 Kota Semarang used 2013 curriculum. There were 11 thematic lessons and $100 \%$ of them contain safety education. The detailed contents for each themes is: Islamic religion $(77 \%)$, mathematics $(14 \%)$, theme 1: the beauty of togetherness $(67 \%)$, theme 2: saving energy $(67 \%)$, theme 3 : caring for living things $(100 \%)$, theme 4 : work division $(100 \%)$, theme 5: my hero $(67 \%)$, theme 6 : my dreams (33\%), theme 7: the beauty of diversity in my country (33\%), theme 8: my hometown $(33 \%)$, theme 9: my country's wealth $(50 \%)$

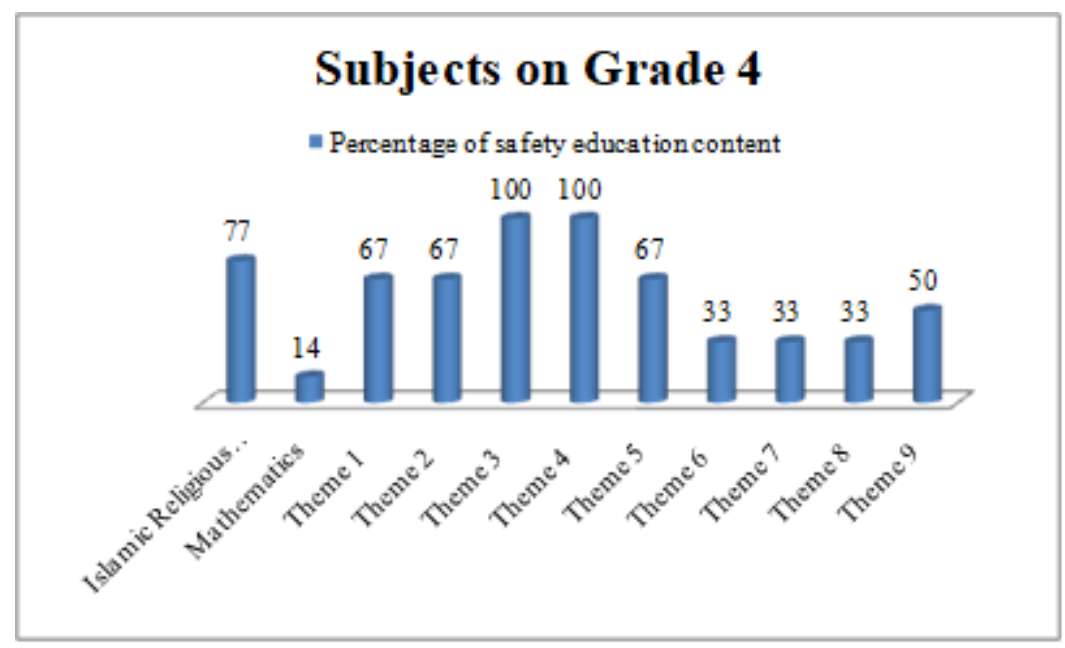

Figure 4. The illustration of safety education in grade 4 of primary school Source: Primary data, 2017

\subsection{The Application of Safety Education in Grade 5 of Primary School}

Grade 5 had 10 subjects and only art \& culture (10\%) does not contain safety education. The other 9 subjects contain safety education with details as follows: natural science (92\%), mathematics (10\%), Indonesian language (63\%), citizenship education (28\%), Islamic religion (25\%), social science (16\%), Javanese language (44\%), sport education (100\%), and caring for self \& environment (72\%).

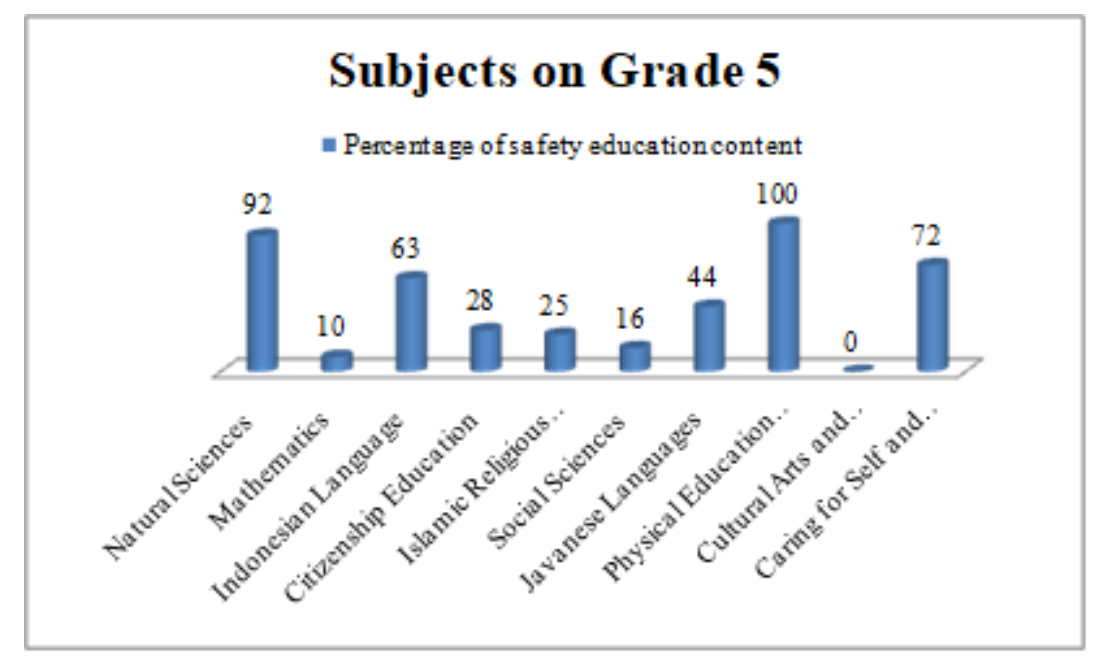

Figure 5. The illustration of safety education in grade 5 of primary school Source: Primary data, 2017 


\subsection{The Application of Safety Education in Grade 6 of Primary School}

Grade 6 had 8 subjects, namely: Indonesian language, natural science, social science, citizenship education, caring for self \& environment, mathematics, and arts \& culture. 4 of 8 subjects (50\%) does not contain any safety lesson, specifically: Indonesian language, citizenship education, mathematics, and art \& culture. The other lessons contain safety education with details as follows: natural science $(88.9 \%)$, social science (50\%), Javanese language (11.11\%), and caring for self \& environment (100\%).

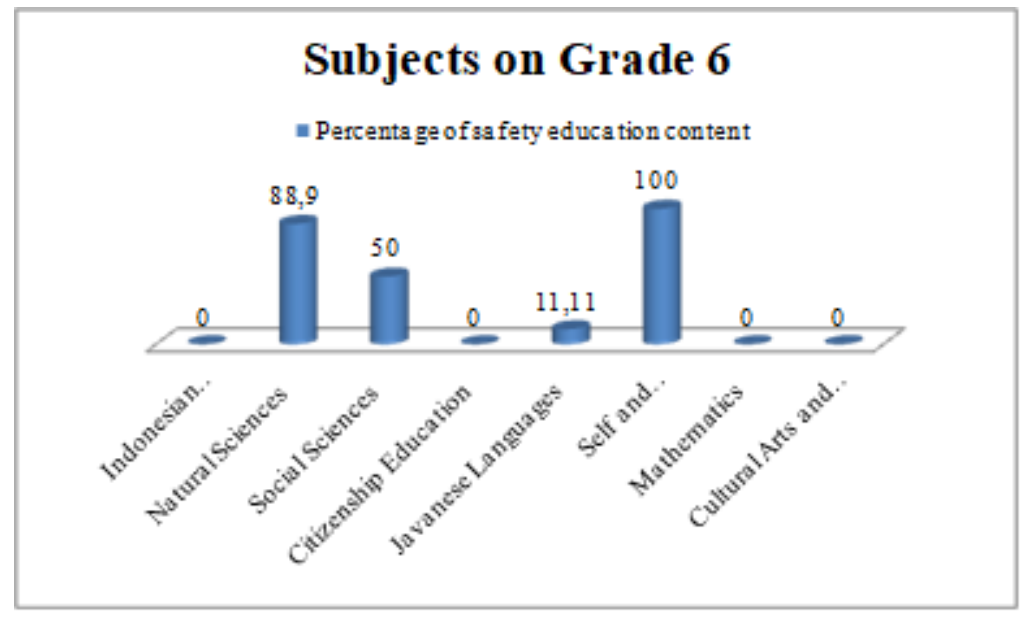

Figure 6 . The illustration of safety education in grade 6 of primary school Source: Primary data, 2017

All six figures above show that subjects given in grade 1 until grade 6 contain safety education, explicitly or implicitly taught, and despite its uneven distribution in terms of subjects and themes.

The government set the curriculum standard, teaching materials, and facilities of Public schools. The quality of safety education in a school is determined by teacher's competency, teaching materials, and available facilities. The existing teaching materials in elementary schools are represented in text books. Dharmadi said that sport safety manuals can be a guidance for teachers and students to prevent accident during sport education [5]. The majority of children admitted that they did not receive any information on self-safety from anyone; therefore, teachers' and parents' role in educating children on self-safety is inadequate [6].

This research revealed that sport education in grade 3 and grade 5 had $100 \%$ applied the safety education. It was very important for teachers to explain all potential hazards and how to conduct activities safely. This research was different with the research by Sukarmin, which found that implementation of safety education in sport education was only in "sufficient" category. Elementary sport teachers are already aware and capable to conduct safe sport education, although not optimal yet because their efforts cannot cover all aspects involved in sport education, especially in non-technical aspects [7].

Safety education is very important to be taught to children as early as possible. Data showed that only $40-50 \%$ students could identify potential hazards and potential risk around them, including: risk for falling from the stairs, slipped due to slippery floors, traffic accident involving motor vehicle, and unsanitary food and environment that cause illness. Not all students could explain safety signs at school, including traffic signs [8].

Every person has different level of knowledge. The level of knowledge starts from knowing, comprehension, application, analysis, synthesis and evaluation. The higher a person's education, the higher the level of knowledge. Knowledge level influence someone's behaviour; therefore children with good knowledge would have good behaviour [9]. Education and training could ultimately change a person's behaviour. One of the goals of education is to make students more skilful in their work and avoid potential hazards around them [10]. In addition, parents and school play an important role in safety education for children. As Alonso [11] has stated that parents' influence and school environment have been considered as positive factors that influence on the road safety education of the children because they are also involved in promoting the safe attitudes and behaviors [11].

Education can be done through formal (in the school) and informal (parents, etc) means. A study by Lai, using one control group and two intervention groups (A and B), where group A who were given a 2 
years-long intervention program consisting of multi-unit presentations plus a series of educational materials resulted a more significant improvement than group B who were given one year-long education materials only. In addition, both groups also demonstrated positive improvement in subjects' behaviour after intervention, although with different degrees of improvement [12].

\section{CONCLUSION}

This research described the application of safety education in elementary schools in Indonesia, as represented by SD Negeri Petompon 2 Semarang. The detailed description is as follows:

a. Grade 1 had 10 thematic subjects with 6 themes $(60 \%)$ contain application of safety education.

b. Grade 2 had 7 subjects and only 1 subject (14,3\%), citizenship education, contain safety education.

c. Grade 3 had 10 subjects, 9 of which (90\%), except art \& culture, contain safety education that is presented explicitly or implicitly.

d. Grade 4 had 11 thematic lessons and all of them (100\%) contain the application of safety education, despite only minimal content provided in the available sub-themes.

e. 7 of 8 subjects $(87,5 \%)$ in grade 5 contain safety education although distributed unevenly.

f. 4 of 8 subjects $(50 \%)$ in grade 6 already contain the application of safety education.

Therefore, we suggest that teachers improve their teaching capacity to be able to improvise on the teaching materials. Competency improvement can be reached by training or enrichment on the existing materials. Improvisation in teaching process can be done by incorporating the values of safety education in all subjects. The objective is to internalize safety culture in all students as early as possible. The following subjects should receive an addition of safety contents: sport education, natural science, social science, citizenship education, Islamic religion, mathematics, and Indonesian language.

\section{ACKNOWLEDGEMENTS}

The implementation of this activities was funded by the "Penelitian Unggulan" Grant Scheme 2017 by Sport Science Faculty, Universitas Negeri Semarang. And we give our greatest gratitude to the services, opportunities, and trust to Universitas Negeri Semarang

\section{REFERENCES}

[1] Susy Kuschithawati, dkk, "Faktor Resiko Terjadinya Cedera Pada Anak Usia Sekolah Dasar", BKM, Vol 23 No 3 , September 2007, pp. 131, 2007.

[2] Profil Kesehatan Provinsi Jawa Tengah, 2012.

[3] Edwin Hidayat, "Evaluasi Tipikal Zona Selamat Sekolah Pada Jalan Arteri Primer Yang Masuk Wilayah Perkotaan, Jalan Jembatan", Volume 26, No. 1, April 2012, pp. 47-57, 2012.

[4] Fitri Evanti Hutasoit dan Evi Widowati, "Gambaran Penerapan Safety Education (Pendidikan Keselamatan) Di Sekolah Dasar”, Journal of Health Education, Volume 2, No. 1, 14 November 2017, pp. 66-72.

[5] Made Agus Dharmadi, I Nyoman Kanca, Ni Luh Putu Tuti Ariani. 2015. Keselamatan Olahraga Melalui Buku Pedoman Keselamatan Dalam Olahraga. Jurnal Ilmu Sosial dan Humaniora, Vol. 4, No. 2, Oktober 2015: 23032898.

[6] Agnes Maria Sumargi, Yohan Kurniawan, James Waskito Sasongko, Ermida Simanjuntak. 2005. Apa yang Diketahui Anak-anak Sekolah Dasar tentang Keselamatan Dirinya: Studi Pendahuluan tentang Pemahaman akan Keselamatan Diri. INSAN, Vol. 7, No. 3, Desember 2005.

[7] Sukarmin, Y., \& Sumaryanti., 2017. Implementasi Pendidikan Keselamatan Dalam Pembelajaran Olahraga. Jurnal Kependidikan, Vol. 1, No. 1, Juni 2017, Hlm 24-37.

[8] Yusvita, Fierdania, 2016. Pendidikan Keselamatan Di Sekolah Pada Siswa/I SDN 11 Pagi Duri Kepa Jakarta Barat. Jurnal Abdimas, Vol.3, No. 1, 1 September 2016, Hlm 45-50.

[9] Diaz-Quijano, F.A., Martínez-Vega, R.A., Rodriguez-Morales, A.J. 2017. Association between the level of education and knowledge, attitudes and practices regarding dengue in the Caribbean region of Colombia. BMC Public Health, 18 (1): 143.

[10] Raharjo, B. B., Handayani, O. W. K., Nugroho, E., \& Hermawati, B. 2016. Local Potentials as Capital for Planning Nutrition Programs for Urban Fringe Areas in Developing Countries. Pakistan Journal of Nutrition, 15 (12): 10261033.

[11] Francisco Alonso, Cristina Esteban, Sergio Useche, Violeta Manso. 2016. Determinants and Stakeholders Influencing Children's Road Safety Education. International Journal of Elementary Education. Vol. 5, No. 6, 2016, pp. 63-68. doi: 10.11648/j.ijeedu.20160506.12.

[12] Dihui Lai, Jianchun Hao, Yu Fu, Shaowei Cheng. 2017. Evaluation of a Sun Safety Education Program for High School Students in Beijing, China. Education Journal. Vol. 6, No. 2, 2017, pp. 94-99. doi: 10.11648/j.edu.20170602.14. 